\title{
A closer look inside collaborative action: civic engagement and participation in community energy initiatives
}

Jörg Radtke*

University of Bremen, Germany

\begin{abstract}
The aim of this study was to characterise factors affecting citizen participation in community energy initiatives. Data came from an online survey of participants in energy cooperatives and similar organisations. The results offer clear evidence that participants are not exclusively profit-orientated; furthermore, they tend to be well-educated, knowledgeable, enjoy a good income, and operate with a strong organisational commitment and dedication to the beneficial effects of energy initiatives. Surprisingly, these factors do not predict active engagement in the organisations. Attendance at meetings may be high, but participants expressed concerns about the lack of transparency in the operations of governing bodies. Although the majority of members in energy initiatives defined their organisations as democratic and showed awareness of their influence and power as individuals, members' aspirations and organisational realities diverged owing to obstacles that constrain these initiatives from realising their full potential as change agents for an environmentally responsible society.
\end{abstract}

Keywords: Community Energy, Participation, Member attitudes, Civic engagement, Motivation, Citizenship.

\section{Introduction}

One of the central challenges faced by contemporary society involves its transition to renewable energy sources. A key role in this transition is played by community energy initiatives, such as energy co-operatives and the like. This study focuses on initiatives which co-operatively own renewable energy systems to generate electricity, in small grassroots projects or through participation in larger social enterprises. The effectiveness of these initiatives depends on civic participation and engagement, on the networks of relationships 
p. 236. A closer look inside collaborative action: civic engagement and participation in community energy initiatives

among people and organisations struggling to negotiate the ever-changing landscape of energy policy and politics. Development of such social capital, particularly in the context of grassroots initiatives, raises issues of organisational democracy and governance, of institutional legitimacy and acceptance - issues that impact society's movement toward sustainable energy.

Numerous research efforts have attempted to explore these issues. One line of inquiry seeks to characterise the various forms of community energy initiatives (Walker/DevineWright, 2008), arguing that these initiatives represent a hybrid organisational form of a social business enterprise (Huybrechts, 2012), shaped by the dynamics of social entrepreneurship and social networks (Dufays and Huybrechts, 2014; Huybrechts, 2013a; Huybrechts, 2013b; Huybrechts and Defourny, 2008; Huybrechts and Nicholls, 2012; van der Horst, 2008). From this perspective, the internal structures of governance of an initiative largely determine the civic participation in and engagement with it (Ison, 2010).

Österberg and Nilsson (2009) go further, identifying active member participation in these internal structures as the "key to trust and commitment" from engaged citizens. Such participation has been found to depend on modes of governance (Ison, 2010), ownership and ownership structures (Warren and McFayden, 2010; Woodin et al,, 2010; Walker, 2008), member responsibilities and competences (Herbert, 2005), equal opportunities between communities (Park, 2012), conflicts, trust, and social capital (Walker et al., 2010), deliberation (Fast, 2013) and power factors (Middlemiss and Parrish, 2010). Relationships and connections to policy makers and the public (Cass, Walker and Devine-Wright, 2010) and network structures linking local communities to energy initiatives (Parag et al., 2013) have also been found to effect participation.

A second line of inquiry examines the integration of external stakeholders in an organisation and how stakeholder interaction impacts civic participation and engagement. Huybrechts et al (2013) claim that the better stakeholders are integrated in the organisational structure of an enterprise, the more "cross-sector collaborations" are possible and the greater is the perceived legitimacy, and hence efficacy, of the organisation. They emphasise that such integration requires a strong will to collaborate on the part of the stakeholders and, further, depends on the choice of partners and the partnership design, both of which are decisive in providing the motivation for and development of collaborative activities. They point out that analysing the factors leading to the creation of successful working collaborations in a civil society requires going beyond simple explanations of utility to encompass the individual characteristics and aspirations of the stakeholders.

Huybrechts and Nicholls (2013) stress the importance of creating organisational legitimacy through collaboration. Such legitimacy arises, on the one hand, out of organisational strategies and resources. On the other hand, members' experience of organisational structure and how that operates as part of a broad social network either adds to or detracts from perceived legitimacy.

A third line of inquiry examines the roles participating members play in an energy initiative. Walker and Cass (2007: 465) define three categories of participation: first, a member may belong to the organising group; second, a member may attend meetings; third, a member may be engaged in "hands on installation and maintenance". These categories are not mutually exclusive, but such participation is only possible for the public in a jointly-orientated initiative. Participation in household initiatives, private energy producers and public institutions such as municipal utilities is typically restricted to a small group of people, making involvement by members of the larger community impossible. 
p. 237. A closer look inside collaborative action: civic engagement and participation in community energy initiatives

From this perspective, the degree of community participation in an initiative is not only one of its distinguishing factors, but also a key factor in sustaining the initiative. As Rogers et al (2008) point out, an energy project initiator's orientation to the community plays a decisive role in shaping the engagement of community members with that initiative.

Building on this line of inquiry is the idea of green citizenship and its impact on civic participation and engagement (Dean, 2001; Smith, 2005; Dobson and Bell, 2006; Gabrielson, 2008; Gabrielson and Parady, 2010; Martinsson and Lundgvist, 2010; Trachtenberg, 2010; Merritt and Stubbs, 2012; Scerri and Magee, 2012; Bell, 2013; MacGregor, 2014). A special concept in this context is that of energy citizenship in the sense of a "Climate Citoyen" who is actively engaged both on the individual level, where the citizen focuses on energy efficiency in the household or workplace, and on the political level, where he or she engages in local, national or international activities related to climate policies, and further makes commitments to action groups, organisations or energy co-operatives that strive for environmentally friendly energy usage (Devine-Wright, 2007; Seyfang, 2007).

As fruitful as these lines of inquiry are, they have mainly relied on qualitative case studies in which disparate criteria have been elaborated to explain the characteristics of specific energy initiatives. Recurring themes include the purpose and objectives of the initiative, influences mediated by external actors, responses to innovations and the potential to advance society's transition to environmentally responsible energy systems. But, as Walker and Devine-Wright (2008) point out, community energy initiatives vary widely in diversity and complexity, making it challenging to elaborate a methodologically sound approach to identifying factors that affect, and so might encourage, civic participation and engagement.

Little quantitative data has been collected that can help identify and characterise these factors. To date, there has been no systematic quantitative investigation into the internal processes of participation, the meanings that citizens assign to their membership, and the extent to which members actually impact energy initiatives through collaboration, codetermination and social learning processes. It is the aim of this article to provide quantitative survey results that can help extend knowledge in this regard.

Specifically, I examine political and social participation in the context of planning renewable energy plants; financial and collaborative participation through membership in co-operatives, involving internal participation in the organisation; and dialogic participation through discourse aimed at reaching consensus in the operation and policies of an initiative. The study characterises citizen engagement in community energy initiatives, identifying socio-demographic structures, shareholder interests, attendance at meetings and frequency of verbal or written statements, an approach that allows dominant conflicts, concerns and challenges to emerge. I further categorise the different types of energy initiatives and participatory models from the perspective of emerging internal organisational structures, seeking to determine whether social capital, sense of community and citizen commitment are measurable. Social capital is defined in this instance using Putnam's two concepts of bonding social capital within the community (member interaction) and bridging social capital as the potential to interact within a local actor network outwith the community (Putnam, 2000). This has been achieved by surveying the attitudes of project members, considering the dimensions of working and interacting together, social cohesion and the creation of a sense of community through identification. 
p. 238. A closer look inside collaborative action: civic engagement and participation in community energy initiatives

A key question driving this research is whether community energy initiatives can be viewed as "schools of democracy" where citizen participation offers a new model for synthesising technology, community, and professional management. In short, to what extent do members of these initiatives actively create and invent new forms of community action in contrast to remaining passive in their financing role as investors?

\section{Methods}

To obtain detailed insights into the factors motivating citizen participation in energy initiatives, along with a profile of socio-demographic characteristics and the philosophical orientations of shareholders, a mixed-methods research design was employed, where quantitative research assessing the magnitude and frequency of constructs was combined with qualitative research exploring the meaning and understanding of these constructs. This method is especially suitable for research questions that call for real-life contextual understandings that require multiple perspectives and consideration of cultural influences. This method is highlighted in the literature, especially where investigations of community energy initiatives are concerned (Rogers et al., 2008; Seyfang et al., 2013).

Citizens who are involved in energy co-operatives, community wind parks, environmental associations and similar organisations have participated in an online survey including both quantitative and qualitative sections (open answers and free text fields). Additionally, interviews with initiators and supporters of eight community energy initiatives with different sizes and technologies (small co-operatives installing photovoltaic systems and larger citizen-owned wind companies) were conducted. The survey was conducted in $2012 / 2013$ and is based on 2,826 respondents from 84 such community energy initiatives. Participants came from initiatives all over Germany, and the initiatives represented all current renewable energy sectors, including solar, wind, biomass and geothermal energy systems. The activity and engagement of citizens within these energy projects were recorded, together with local conditions. Survey participants were also asked to assess the structure, organisation and management of their energy projects. Finally, conflict situations, criticism and social cohesion within the communities were considered.

\section{Results}

The first set of findings offers insight into the demographic profile of participants. Key survey results are summarised below.

\section{Social Structure of Respondents}

Age: 54 per cent are between 45 and 64 years old.

Gender: 80 per cent are male.

Education: 57 per cent are well-educated holding a university degree.

Income: 49 per cent have gross monthly incomes of at least $€ 3,500$.

Commitment: 80 per cent are members of a civil society organization. 
p. 239. A closer look inside collaborative action: civic engagement and participation in community energy initiatives

These results indicate that the majority of participants are middle-aged, well-educated and most have comfortable incomes. This is not representative of the larger society, as socially disadvantaged strata of the population represent a clear minority. Furthermore, 52 percent of the respondents indicated that had invested more than $€ 3,000$ in their participation, a relatively high capital investment that effectively excludes lower income groups from engagement.

These findings reflect the fact that community energy initiatives often create little new social capital, as they bond already committed and engaged individuals. Participation may be seen as an element of the social structure of higher income groups with advanced academic degrees. This corresponds to the typical profile of the standard socio-economic structural model of civic engagement and participation (Verba and Nie, 1972). However, as illustrated by energy co-operatives, initiatives do arise where participants invest smaller sums, and, in almost half these cases, people with lower levels of education are well represented. People at low income levels, however, remain strongly under-represented.

The next set of findings examines individual motivation for participation.

\section{Respondent Motivation and Experience}

Motivation: 93 per cent indicate that their involvement is primarily for ecological reasons. 56 per cent indicate that their participation is profit orientated.

Knowledge: 36 per cent know the locations of the power plants with which they are involved.

Experience: 52 per cent have previous experience with renewable energy projects.

Level of information: 95 per cent say they are well informed about the energy project.

Motivation of participants with high amounts of investment is more orientated to investment return and less to support for environmental reasons, while the activities of members with low investment are more focused on ecological returns. In terms of motivation for engagement, the return incentive can be regarded as one aspect amongst other motivations and may not be the decisive one compared to environmental and selfsufficiency factors.

The next set of findings examines member participation and engagement explicitly.

\section{Respondent Participation and Involvement}

Participation in meetings: 76 per cent say they participate in meetings.

Comments: 89 per cent express themselves frequently in the members' meetings. Issues: 11 per cent emphasise the importance of organisational issues. 
p. 240. A closer look inside collaborative action: civic engagement and participation in community energy initiatives

\section{Participation in Discourse and Discussion}

Call for Ideas: 46 per cent of the represented organisations have a period in meetings where members are called on to contribute ideas.

Input: 19 per cent of respondents indicate that they have to date offered at least one idea.

Discussion: 14 per cent indicate the desire for more discussions within the community.

While there is a high degree of participation in meetings, less than half of the energy initiatives explicitly ask for members to contribute ideas. This may explain the relatively low proportion of respondents having input ideas or suggestions to projects. On the other hand the fact that almost one-fifth have contributed their ideas to projects might actually represent significant member engagement when compared to other participation processes such as for political parties, clubs or citizen forums. Members indicated that conflict resolution processes within the forums are largely effective, and openness to critical evaluation of ideas seems established.

The next set of findings deals with how members view the organisational structure and internal operations of their initiatives.

\section{Respondent Views of Organisational Democracy}

Definition of democracy: 69 per cent consider decisions made by their initiative to be democratic.

Statement of democracy: 54 per cent identify the existence of voting rights as the factor that makes their energy initiative democratic.

Co-determination: 60 per cent are unsure whether or not they want more co-determination.

Although community energy initiatives are private companies in a strict sense and so are not necessarily classified as democratic institutions, these results show that a large majority of the members consider their initiative to be democratic. Voting and collective decision-making are the principal reasons given for this attribution.

\section{Respondents' Sense of Community}

Community: 60 per cent feel a sense of community within the project.

Identity: 85 per cent say they identify with their energy project.

Criticism: 47 per cent say criticism within the project is infrequent.

Conflict: 15 per cent say that conflicts are not resolved in the project.

To a large extent, members in energy initiatives work from a sense of belonging, personal identification and commitment to the initiative (through capacity building in order to create engagement, empowerment and social capital). This finding clearly refutes the idea of a silent uninvolved membership acting as passive investors in community energy projects (e.g. Walker and Devine-Wright, 2008). Members also think much more in terms of the collective benefits of their initiative, namely its contribution to the energy transition, 
p. 241. A closer look inside collaborative action: civic engagement and participation in community energy initiatives

than they do of individual benefits serving their self-interest (thereby developing democratic skills). The Germany Energy Transition has cemented itself in the collective awareness of members as a long-term social endeavour with which individual citizens can strongly identify.

The next set of findings addresses members' perceptions of the social effects mediated by their energy initiatives.

\section{Respondents View of Social Effects}

Acceptance: 53 per cent of respondents felt that the local community would perceive their energy facilities positively.

Effects: 41 per cent of respondents support more collaborative projects in society, based on their experiences as participants in a community energy initiative.

Community energy generates trust in community energy production, so it is not surprising to find that members express interest in becoming involved in additional renewable energy projects and generally favour a more active citizenry. Community energy clearly increases faith and trust in local community action as well as in the use of renewable energies. Interestingly, members do not experience growing opposition towards conventional electricity production, nor do they embrace uncritically every renewable energy installation, but rather discriminate thoughtfully and weigh benefits against potential detrimental effects.

Taken as a whole, these results indicate that participation in energy initiatives derives its motivation from long-term social concerns and not exclusively from profit seeking. High levels of income and education - including existing knowledge of renewables and insight into energy issues - correlate with membership in the initiatives. Such membership is decidedly not passive, rather evincing strong commitment to the organisation and dedication to its beneficial effects. The activity of citizens within the initiatives, however, is less marked; attendance at meetings is commonly high, but large variations exist among energy projects.

The majority of engaged citizens define their energy projects as democratic and voice support for and awareness of the possibilities for constructive societal change through their individual and collective creative efforts. These same citizens, however, often express dissatisfaction with the lack of transparency in the operations of governing bodies, finding that the guiding policies behind operations are not openly discussed with the wider membership.

Qualitative survey data indicates that many members share this concern, with a commonly submitted resolution being to give the members more online opportunities to participate and to provide them with more online distribution of information. This suggestion notwithstanding, the overwhelming majority of respondents (95 per cent) say they feel well-informed. It is not clear, however, to what degree this sense of being wellinformed relates to renewable energy as a whole, the German Energy Transition, or the dayto-day operations of the energy initiative.

In addition to calling for more online participation and information, respondents also argue for more opportunities to contribute to discussion, greater involvement in decisionmaking, inclusion in company management and on corporate boards, and more flexibility in 
p. 242. A closer look inside collaborative action: civic engagement and participation in community energy initiatives

the instruments available for financial participation. Respondents also voiced concerns about limitations for public engagement and networking. Interested persons are sometimes barred from membership in a community energy initiative, whether because of oversubscription, caps on membership, minimum investments, or other causes.

Finally, a loose correlation could be observed between the size of community energy initiatives and the level of member participation. Small energy cooperatives tend to function in a more participatory and open manner than do larger projects, where citizens often feel relegated to the role of silent shareholder. This generalisation is hardly a fixed relationship, and exceptions are not only feasible but regularly encountered in practice. However, the results confirm the trend that small and local initiatives do tend to be more participatory and open.

\section{Discussion}

The study has found that community energy initiatives have the potential to empower citizens struggling to negotiate the opportunities, constraints and risks associated with the contemporary transition to renewable energy. These initiatives further provide other positive effects, such as capacity building in the form of group learning and helping to increase democratic competences. However, not every citizen is equipped with the requisite socio-economic resources for access to energy initiatives. The initiatives tend to generate little new social capital and rather align themselves with those who already have an affinity to specific ways of participating in groups, political parties and organisations.

These findings are particularly evident in those municipal domains where the operation of and planning for energy initiatives takes place. Each implementation incurs its own risks and offers its own opportunities. A danger exists that economic motives can overshadow environmental commitments, meaning returns on investment are prioritised or pursued under the guise of environmental commitment.

It can thus be helpful to consider the following systematic classification based on interpreting the results of community energy initiatives. This is based on drawing out the key themes from the survey data into a set of broad variables that aim to classify community energy initiatives across two axes: 'motivation' and 'identification'. This uses a set of four variables, which take both the individual perceptions of the respondents as well as aspects of legal and participative issues into account and offers scale coordinates on which a specific initiative can be situated. These variables are defined as follows:

1. Size of the initiative and legal form: community energy initiative as the member collective or as a representative actor: Activities range from highly collectivecollaborative, to somewhat collaborative, to activity restricted to formal boards with exclusion of informal participation and isolationist attitudes.

2. Demand for and use of participation opportunities: participation and democracy as bringing in and co-determination: Activities range from rejection, limited use and neutral attitude up to active use and claims of extensions. 
p. 243. A closer look inside collaborative action: civic engagement and participation in community energy initiatives

3. Shaping of activity tools: Activity as a collaboration and co-creation: Activities range from rejection, limited to business-use or thematic reference up to the idea of community and social interaction.

4. Definition of participation: Individual definition of participation: Attitudes range from silent partnership without idealistic motivation, through moderate activity with ethical motivation up to an active role with strongly idealistic motivation in form of community sense and strong participation.

\section{A Typology of Member Participation Types}

Based on the results from this study, and analysing across each of the variables outlined above, a range of participation types can be distinguished, each shaped by specific member motivations and attitudes. The first three types characterise citizen motivation for participation, while the second three characterise the identification of members with and their way of acting in the initiatives. Both typologies represent two different views of each and every individual membership.

\section{X1 "Ecological attitude"}

Motivation: Contribution to renewable energy policy and environmental goals.

Participation in the Community: Perceived as less relevant.

Definition: The community energy initiative exists primarily to supply renewable energy; other claims are not relevant.

Allocation: The largest group of members in each community energy initiative, especially in participation certificate initiatives.

\section{X2 "Structural conservatism attitude"}

Motivation: Mixed, undifferentiated motives.

Participation: Only when accompanied by explicit aspirations.

Definition: The community energy initiative should work by established professional management; anything beyond that is less useful. Activities and participation are intended to refer only to formal procedures and places.

Allocation: Found in all community energy initiatives. High proportion of university graduates and people with high incomes.

\section{X3 "Investor attitude"}

Motivation: Financial incentives.

Participation: In part or strongly disclaimed. Indifferent attitude to activity of third parties.

Definition: The community energy initiative is expected to produce the highest possible income return. Activities and participation are sometimes perceived as disturbing.

Allocation: Found in all community energy projects. 
p. 244. A closer look inside collaborative action: civic engagement and participation in community energy initiatives

The following three types are represented more strongly in some community energy initiatives than in others:

\section{Y1 "Independent-orientated mentality"}

Motivation: "Citizen-owned energy", secondary profit orientation.

Participation: Pragmatic, active role, but not as a value in itself. Too much input and activity will be not accepted.

Definition: The community energy initiative should function as an independent actor, achieving a high degree of independence, self-reliance and self-sufficiency.

Allocation: Widespread, especially in community wind parks. Congruent to the type is "structure conservatism". Dominating liberal-conservative orientation of the members.

\section{Y2 "Participatory mentality"}

Motivation: Participative-collaborative design and community involvement, strong attachment to and aspiration for participation in the energy initiative. Low yield-orientation.

Participation: Should be as strong as possible.

Definition: The energy initiative exists as a place of community.

Allocation: Especially in co-operatives. High number of academics. Also contains a dissatisfied and frustrated nucleus of members in co-operatives. Subset of type 1 "Ecological attitude". Dominating ecological and social orientation of the members.

\section{Y3 "Association loyalty mentality"}

Motivation: Primarily ecological, secondary income return orientation.

Participation: Less important. Strong attachment and commitment to the investment organization (mostly environmental association, e.g. Greenpeace) which acts as a representative actor and deputy of its members.

Definition: Idea of an active role in energy policy of the association as a multiplayer. Pragmatic, action-orientated alignment without connection to the idea of forming a local community.

Allocation: Mainly participation certificate initiatives as an element of environment protection groups or larger, national acting community energy companies (mainly via participation rights), also in the form of loans from environmental organisations and associations, partially bound to larger energy co-operatives. Very strong "ecological attitude" (type 1). Dominating pragmatic action orientation of the members. 
p. 245. A closer look inside collaborative action: civic engagement and participation in community energy initiatives

Complementing these types of member motivation three modes of participation can be summarized:

1. Cultural and social participation: in the context of events, where participation and governance is collaborative and social;

2. Political and organisational participation: where co-determination is the rule, voting and incorporation of ideas and issues makes for participation in decisionmaking;

3. Financial and economic participation: in the form of financial shares, where the participatory mode is monetary.

\section{Conclusion}

The results provide evidence of a great variety of grassroots initiatives with bottom up participation opportunities (Seyfang and Haxeltine, 2013; Hargreaves et al., 2013; Seyfang et al., 2013/2014; Smith and Seyfang, 2013) and top down processes of larger projects with a more professional management. It seems to be proven that smaller bottom up cooperatives are more participative and represent a stronger active and committed community. Additionally characteristics such as place identity and local engagement in specific actor networks are also multifaceted (Devine-Wright and Clayton, 2010; DevineWright, 2011). It can be suggested that the ideas of Benjamin Barber's Strong Democracy (Barber, 1984), as well as the ideas of participatory democracy (Pateman, 1970) and collaborating communities (Sennett, 2012) are rather idealistic considering the limited resources of individuals such as time and capacities (Bomberg and McEwen, 2012). However, positive effects are undeniable. The engagement in such initiatives leads to more interest in common citizen participation and local community projects (and it can be claimed as one of the remarkable results of this study). Social capital building (Putnam, 2000) noticeably occurs in the form of bonding social capital within the communities, rather than bridging social capital. The later appears only in homogenous social structure, where collaborating actors largely remain amongst themselves. A higher degree of legitimacy is achieved with the potential to integrate local communities and reaching more acceptance of renewable energy facilities. Finally, it can be suggested that the individual role of participants within the initiatives is highly fluctuating between an idealistic civic virtue Citoyen in the sense of Jean Jacques Rousseau and an economic citizen remaining a stakeholder with investor mentality, but with the advantage of good conscience. However, in reality the characteristics, motivations and behaviours of each individual are mixed, so potentially the gap is closed through the common and unifying goal of implementing environmentally friendly technology.

Considering the individual motivations and interests of members, as well as real world conditions within the initiatives, this study has identified three social contexts in which community energy initiatives play an active role.

1. Community energy initiative as a place of identity, where the local connections between members predominate;

2. Community energy initiative as a place of community, where members gather in shared community concerns and responsibilities; 
p. 246. A closer look inside collaborative action: civic engagement and participation in community energy initiatives

3. Community energy initiative as a place of professional decision-making, where members profit from the market activities of the initiative while deriving emotional gains as well.

\section{Acknowledgements}

Jörg Radtke gratefully acknowledges Kellner \& Stoll - Stiftung für Klima und Umwelt and Stiftung der Universität Bremen for financial support.

* Correspondence address: Jörg Radtke, Universität Bremen, Department of Anthropology and Cultural Research, Postfach 330 440, 28357 Bremen, Germany. Email: radtke@unibremen.de

\section{References}

Barber, B. R. (1984) Strong democracy: participatory politics for a new age. Berkeley: University of California Press.

Bell, D. (2013) Environmental citizenship: global, local and individual, In: P.G. Harris, Routledge Handbook of Global Environmental Politics. London: Routledge, 347-358.

Bomberg, E. and McEwen, N. (2012) Mobilizing community energy. Energy Policy, 51, 435444.

Cass, N., Walker, G. and Devine-Wright, P. (2010) Good neighbours, public relations and bribes: the politics and perceptions of community benefit provision in renewable energy development in the UK. Journal of environmental policy \& planning, 12, 255275.

Dean, H. (2001) Green citizenship. Social policy \& administration, 35, 490-505.

Devine-Wright, P. (2007) Energy Citizenship: Psychological Aspects of Evolution in Sustainable Energy Technologies, In: J. Murphy, Governing Technology for Sustainability. London: Earthscan, 63-88.

Devine-Wright, P. (2011) Place attachment and public acceptance of renewable energy: A tidal energy case study. Journal of Environmental Psychology, 31, 4, 336-343.

Devine-Wright, P. and Clayton, S. (2010) Introduction to the special issue: Place, identity and environmental behaviour. Journal of Environmental Psychology, 30, 3, 267-270.

Dobson, A. and Bell, D. (2006) Environmental citizenship. London/Cambridge: MIT Press.

Dufays, F. and Huybrechts, B. (2014) Connecting the Dots for Social Value: A Review on Social Networks and Social Entrepreneurship. Journal of Social Entrepreneurship, 5, 214-237.

Fast, S. (2013) A Habermasian analysis of local renewable energy deliberations. Journal of Rural Studies, 30, 86-98.

Gabrielson, T. (2008) Green citizenship: a review and critique. Citizenship studies, 12, 429446.

Gabrielson, T. and Parady, K. (2010) Corporeal citizenship: rethinking green citizenship through the body. Environmental politics, 19, 374-391. 
p. 247. A closer look inside collaborative action: civic engagement and participation in community energy initiatives

Hargreaves, T., Hielscher, S., Seyfang, G. and Smith, A. (2013) Grassroots innovations in community energy: The role of intermediaries in niche development. Global Environmental Change, 23, 5, 868-880.

Herbert, S. (2005) The Trapdoor of Community. Annals of the Association of American Geographers, 95, 850-865.

Huybrechts, B. (2010) The governance of fair trade social enterprises in Belgium. Social Enterprise Journal, 6, 110-124.

Huybrechts, B. (2013a) Social Enterprise, Social Innovation and Alternative Economies: Insights from Fair Trade and Renewable Energy, In: H.-M. Zademach and S. Hillebrand (eds) Alternative Economies and Spaces. New Perspectives for a Sustainable Economy. Bielefeld: Transcript, 113-130.

Huybrechts, B. (2013b) The role of networks in gaining legitimacy for hybrid organizations: the case of renewable energy source cooperatives (REScoops). transition pour nos sociétés? Thème 6 Les acteurs non-étatiques de la transition, 61-82.

Huybrechts, B. and Defourny, J. (2008) Are fair trade organisations necessarily social enterprises? Social Enterprise Journal, 4, 186-201.

Huybrechts, B., Mertens de Wilmars, S. and Rijpens, J. (2014) Explaining stakeholder involvement in social enterprise governance through resources and legitimacy, In: J. Defourny and L. Hulgard and V. Pestoff (eds) Social Enterprise and the Third Sector: Changing European Landscapes in a Comparative Perspective. New York: Routledge, 157-175.

Huybrechts, B. and Nicholls, A. (2012) Social entrepreneurship: definitions, drivers and challenges. Social Entrepreneurship and Social Business, 31-48.

Huybrechts, B. and Nicholls, A. (2013) The role of legitimacy in social enterprise-corporate collaboration. Social Enterprise Journal, 9, 130-146.

Ison, N. (2010) Governance of Community Energy Projects. Independent Research Project, Lancaster Environment Centre.

MacGregor, S. (2014) Ecological citizenship, in: Heijden, In: H.A. van der Heiden (ed) Handbook of Political Citizenship and Social Movements. Northampton: Edward Elgar, 107-132.

Martinsson, J. and Lundqvist, L.J. (2010) Ecological citizenship: coming out "clean" without turning "green"? Environmental politics, 19, 518-537.

Merritt, A. and Stubbs, T. (2012) Incentives to Promote Green Citizenship in UK Transition Towns. Development, 55, 96-103.

Middlemiss, L. and Parrish, B.D. (2010) Building capacity for low-carbon communities: The role of grassroots initiatives. Energy Policy, 38, 7559-7566.

Österberg, P. and Nilsson, J. (2009) Members' perception of their participation in the governance of cooperatives: the key to trust and commitment in agricultural cooperatives. Agribusiness, 25, 181-197.

Parag, Y., Hamilton, J., White, V. and Hogan, B. (2013) Network approach for local and community governance of energy: The case of Oxfordshire. Energy Policy, 62, 10641077.

Park, J.J. (2012) Fostering community energy and equal opportunities between communities. Local Environment, 17, 387-408.

Pateman, C. (1970) Participation and democratic theory. Cambridge: Cambridge University Press.

Putnam, R. D. (2000) Bowling alone: the collapse and revival of American community. New York, NY: Simon \& Schuster. 
p. 248. A closer look inside collaborative action: civic engagement and participation in community energy initiatives

Rogers, J.C., Simmons, E.A., Convery, I. and Weatherall, A. (2008) Public perceptions of opportunities for community-based renewable energy projects. Energy Policy, 36, 4217-4226.

Scerri, A. and Magee, L. (2012) Green householders, stakeholder citizenship and sustainability. Environmental Politics, 21, 387-411.

Sennett, R. (2012) Together: The Rituals, Pleasures and Politics of Cooperation. New Haven, CT: Yale University Press.

Seyfang, G. (2006) Ecological citizenship and sustainable consumption: Examining local organic food networks. Journal of Rural Studies, 22, 383-395.

Seyfang, G. and Haxeltine, A. (2012) Growing grassroots innovations: exploring the role of community-based initiatives in governing sustainable energy transitions. Environment and Planning-Part C: Government and Policy, 30, 381-400.

Seyfang, G., Park, J.J. and Smith, A. (2013) A thousand flowers blooming? An examination of community energy in the UK. Energy Policy, 61, 977-989.

Seyfang, G., Hielscher, S., Hargreaves, T., Martiskainen, M. and Smith, A. (2014) A grassroots sustainable energy niche? Reflections on community energy in the UK. Environmental Innovation and Societal Transitions, 13, 21-44.

Smith, A. and Seyfang, G. (2013) Constructing grassroots innovations for sustainability. Global Environmental Change, 23, 5, 827-829.

Smith, G. (2005) Green citizenship and the social economy. Environmental Politics, 14, 273-289.

Trachtenberg, Z. (2010) Complex green citizenship and the necessity of judgement. Environmental Politics, 19, 339-355.

Van der Horst, D. (2008) Social enterprise and renewable energy: emerging initiatives and communities of practice. Social Enterprise Journal, 4, 171-185.

Verba, S. and Nie, N. H. (1972) Participation in America. New York: Harper \& Row.

Walker, G. (2008) What are the barriers and incentives for community-owned means of energy production and use? Energy Policy, 36, 4401-4405.

Walker, G. and Cass, N. (2007) Carbon reduction, "the public" and renewable energy: engaging with socio-technical configurations. Area, 39, 458-469.

Walker, G. and Devine-Wright, P. (2008) Community renewable energy: What should it mean? Energy Policy, 36, 497-500.

Walker, G., Devine-Wright, P., Hunter, S., High, H. and Evans, B. (2010) Trust and community: Exploring the meanings, contexts and dynamics of community renewable energy. Energy Policy, 38, 2655-2663.

Warren, C.R. and McFadyen, M. (2010) Does community ownership affect public attitudes to wind energy? A case study from south-west Scotland. Land Use Policy, 27, 204213.

Woodin, T., Crook, D., Carpentier, V. and Joseph Rowntree Foundation (2010) Community and mutual ownership: a historical overview. York: Joseph Rowntree Foundation. 